\title{
Effects of Nigella sativa (Habbatus sauda) Oil and Nicotine Chronic Treatments on Sperm Parameters and Testis Histological Features of Rats
}

\author{
Ng Cho Ping, ${ }^{1}$ Noor Hashida Hashim, ${ }^{2}$ and Durriyyah Sharifah Hasan Adli ${ }^{3}$ \\ ${ }^{1}$ Institute of Graduate Studies, University of Malaya, 50603 Kuala Lumpur, Malaysia \\ ${ }^{2}$ Center for Foundation Studies in Science, University of Malaya, 50603 Kuala Lumpur, Malaysia \\ ${ }^{3}$ Institute of Biological Sciences, Faculty of Science, University of Malaya, 50603 Kuala Lumpur, Malaysia \\ Correspondence should be addressed to Noor Hashida Hashim; nhhpasum@um.edu.my
}

Received 16 February 2014; Revised 12 April 2014; Accepted 4 May 2014; Published 21 May 2014

Academic Editor: Andreas Sandner-Kiesling

Copyright ( $2014 \mathrm{Ng}$ Cho Ping et al. This is an open access article distributed under the Creative Commons Attribution License, which permits unrestricted use, distribution, and reproduction in any medium, provided the original work is properly cited.

\begin{abstract}
Twenty-four Sprague-Dawley male rats (7-9 weeks old, 200-250 g) were divided into Nicotine (N) (0.5 mg/100 g body weight (BW), Nicotine Control (NC) (saline, $0.1 \mathrm{~mL} / 100 \mathrm{~g}$ BW), Habbatus sauda oil (HS) (6.0 $\mu \mathrm{L} / 100 \mathrm{~g} \mathrm{BW),} \mathrm{and} \mathrm{Habbatus} \mathrm{sauda} \mathrm{Control} \mathrm{(HSC)}$ (corn oil, $0.1 \mathrm{~mL} / 100 \mathrm{~g}$ BW) groups and treated for 100 days. Sperm parameters and seminiferous tubules measurements were evaluated. The $\mathrm{N}$ showed a significantly lower sperm motility $\left(1.03 \pm 0.05 \times 10^{6}\right.$ sperm $\left./ \mathrm{mL}\right)$ and percentage of normal $(82.61 \pm 0.03 \%)$ and live $(93.88 \pm 0.01 \%)$ sperm, higher value for the seminiferous tubule $(253.36 \pm 1.83 \mu \mathrm{m})$ and lumen $(100.15 \pm 2.38 \mu \mathrm{m})$ diameters and spermatogonia $(19.85 \pm 0.39 \mu \mathrm{m})$ and spermatocytes $(33.37 \pm 0.59 \mu \mathrm{m})$ layers, and thinner spermatid-sperm layer $(22.14 \pm 0.71 \mu \mathrm{m})$ than the NC $(P<0.05)$. The HS had significantly higher sperm motility $\left(1.49 \pm 0.04 \times 10^{6}\right.$ sperm $\left./ \mathrm{mL}\right)$ and percentage of normal $(90.61 \pm 0.01 \%)$ and live $(96.98 \pm 0.01 \%)$ sperm, smaller lumen diameter $(67.53 \pm 2.34 \mu \mathrm{m})$ and thinner spermatogonia $(17.67 \pm 0.32 \mu \mathrm{m})$ and wider spermatid-sperm $(36.95 \pm 0.79 \mu \mathrm{m})$ layers than the HSC $(P<0.05)$. This research confirmed that nicotine reduced sperm motility and morphology of normal and live sperms and also affected the testis histology, while Habbatus sauda oil increased sperm quality and gave better testis histological features.
\end{abstract}

\section{Introduction}

Infertility is a major medical problem worldwide affecting $10-15 \%$ of couples globally. Infertility is demonstrated by the inability of female to become pregnant after 12 months of unprotected intercourse [1]. Male infertility is more prevalent compared to female [2] and one of the major factors that lead to infertility in male is smoking. The major constituents of cigarette smoke that affect health are nicotine and tar in the particulate phase and carbon monoxide in the gaseous phase [3]. Nicotine is considered as one of the most toxic and detrimental substances that can be found in tobacco smoke [4]. It is an alkaloid found mainly in plants and is present in high concentrations in tobacco (Nicotiana tabacum). Besides being a natural insecticide [5], nicotine is pharmacologically active and has a negative impact on the reproductive system and fertility of males $[6,7]$.
In contrast, there are traditional practices involving the use of plants for their fertility enhancing and aphrodisiac properties $[8,9]$. This is partly reflected by a report from the World Health Organization (WHO) which stated that traditional medicine is used as the primary healthcare product by approximately $70-80 \%$ of the world population [10]. There were various plants used as traditional medicine such as Camellia sinensis, Carica papaya, Thymus vulgaris, and Nigella sativa. One of these plants is Nigella sativa (Habbatus sauda), a plant from the Ranunculaceae family which grows abundantly in several Middle Eastern and Southern Mediterranean countries [11]. Habbatus sauda is from the Arabic term Habat-ul-Sauda and is referred to as Kalonji in South Asia, besides having the English name which is Black Cumin [12]. Seeds of Nigella sativa are used primarily as spice, in addition to being used as traditional medicine in numerous countries [13-15]. Essential oil compounds contained in the seeds 
of Nigella sativa have also been found to contribute to its various biological activities [16]. The major and active component of Nigella sativa is essential oil identified as thymoquinone as has been revealed by pharmacological studies [17]. Thymoquinone possesses a potent antioxidant effect, which could protect organs from oxidative damage by free radical generating agents $[18,19]$. In relation to fertility, it was reported that oral administration of Nigella sativa oil on rats with hypercholesterolemia increased their reproductive performance, weight of seminal vesicle, level of testosterone, sperm motility, and sperm quality [20]. Oral administration of oil extracted from seeds of Nigella sativa for a period of 53 days has also shown improved male rat fertility [21]. This agrees well with the report that black seeds contain alkaloids and phenols, which could stimulate the secretion of testosterone and follicle stimulating hormone (FSH) [22]. The increased levels of testosterone and FSH in testicular tissue have been shown to increase sperm concentration [23]. To date, data concerning the medicinal use of Habbatus sauda oil on reproductive performance and testicular dysfunction is still lacking. Hence, the aims of this research were to provide relevant data on the effects of Habbatus sauda oil and nicotine on sperm parameters and testis histological features of rats.

\section{Materials and Methods}

2.1. Animal Maintenance. Twenty-four male Sprague-Dawley rats (7-9 weeks) with an average weight of 200-250 g were used in this experiment. Water and food in the form of standard pellets were given ad libitum to the rats. Wood shavings were used as bedding, which covered the bottom of cages to absorb urine. The bedding would be changed on an average of every three days to maintain a clean environment for the rats and to reduce unnecessary infection.

2.2. Experimental Design. The rats were randomly divided into four groups: Nicotine (N), Nicotine Control (NC), Habbatus sauda (HS), and Habbatus sauda Control (HSC) groups. Rats in the N and NC groups were intramuscularly injected with nicotine at $0.5 \mathrm{mg} / 100 \mathrm{~g}$ body weight and saline at $0.1 \mathrm{~mL} / 100 \mathrm{~g}$ body weight, respectively. Rats in the HS and HSC groups were force-fed with Habbatus sauda oil at $6.0 \mu \mathrm{L} / 100 \mathrm{~g}$ body weight and corn oil at $0.1 \mathrm{~mL} / 100 \mathrm{~g}$ body weight, respectively. Pure Habbatus sauda oil (Doğaci, Turkey) was diluted with corn oil, which acted as control for Habbatus sauda. Treatments were carried out for 100 days and rats were sacrificed on day 101. Abstracted epididymides were immersed in Toyoda Yokoyama Hoshi (TYH) medium, which was added with Bovine Serum Albumin (BSA) (SIGMA A7030-10 g) prior to sperm parameters evaluation. The protocols used were approved by the Institutional Animal Care and Use Committee, University of Malaya (UM IACUC), with the reference number of ISB/20/04/2012/DSHA (R).

2.3. Sperm Parameter Evaluation. The abstracted cauda epididymides were transferred into $10 \mathrm{~mL}$ of Toyoda Yokoyama
Hoshi (TYH) medium added with Bovine Serum Albumin (BSA) prior to sperm motility evaluation. The sperm suspension was kept in a $\mathrm{CO}_{2}$ incubator (Heal Force $\mathrm{CO}_{2}$ incubator) with $5.0 \% \mathrm{CO}_{2}$ at $37^{\circ} \mathrm{C}$. An aliquot of $40.0 \mu \mathrm{L}$ was pipetted from the sperm suspension onto a haemocytometer slide (Improved Neubauer by Hirschmann Techcolor). The haemocytometer was then left at room temperature for 5 minutes to allow sedimentation of the sperm to the grid of the counting chamber, prior to observation under a light microscope (Olympus CX21FS1) with 20x (phase contrast) objective lens. Sperm motility assessment was performed in accordance with the method as suggested in NAFA and ESHRE-SIGA, Laboratory Manual [24]. The vitality and morphology of sperm were analyzed using eosin-nigrosin (eosin Y: MERCK, 1.15935.0025) (nigrosin: MERCK, 1.15924.0025) staining technique. An aliquot of $50.0 \mu \mathrm{L}$ sperm suspension was mixed thoroughly with $50.0 \mu \mathrm{L}$ of eosin-nigrosin stain on a clean petri dish. Next, $15.0 \mu \mathrm{L}$ of the stained sperm mixture was transferred onto a glass slide and five smears were made for each rat. The glass slides were then left to dry at room temperature before being observed under a light microscope for vitality; live cells appeared to be colourless and dead cells appeared to be red or pink in colour. Approximately 200 sperms were observed for dead and live cells and the percentage of dead and live cells was recorded. As for sperm morphology, another 200 sperms were accessed for normal and abnormal head and tail defects. Classification of sperm morphology and vitality was in accordance with the guidelines as stipulated in the WHO Laboratory Manual [25].

2.4. Testis Histological Features. The abstracted testes were fixed in Bouin's solution for 48 hours at room temperature. Fixed testes were trimmed transversely into three parts. The middle part was then immersed in $70 \%$ alcohol followed by immersions in a series of alcohol solutions with ascending concentrations. After a dehydration process, the tissue samples were then processed further before being sectioned using a rotary microtome. A small drop of Mayer's Albumin was placed at the centre of the glass slide and spread evenly using a cleaned finger. A drop of distilled water was then placed on the same glass slide and tissue sections were transferred onto the slide. The glass slides were dried and kept in a slide box. Haematoxylin and eosin (H\&E) staining technique would stain the nucleus purple and the cytoplasm pink. The steps of the H\&E staining technique included deparaffinization, hydration, haematoxylin and eosin staining, dehydration, and clearing. The features evaluated were the diameter of seminiferous tubules, diameter of lumen, and width of spermatogonia layer, spermatocytes layer, and spermatid-sperm layer.

2.5. Statistical Analysis. Data obtained were analyzed using the Statistical Package for Social Sciences (SPSS) programme. All percentage data were subjected to arcsine transformation before statistical analysis was done. Data were analyzed through analysis of variances (ANOVA) with significant levels of $P<0.05$. 
TABLE 1: Sperm motility, morphology, and vitality of Nicotine (N) and Nicotine Control (NC) groups.

\begin{tabular}{|c|c|c|c|c|c|c|}
\hline \multirow{2}{*}{ Parameter } & \multirow{2}{*}{$\begin{array}{c}\text { Motility }\left(\times 10^{6} \text { sperm } / \mathrm{mL}\right) \\
(\text { mean } \pm \text { SE })\end{array}$} & \multicolumn{3}{|c|}{ Morphology (\%) (mean \pm SE) } & \multicolumn{2}{|c|}{ Vitality (\%) (mean \pm SE) } \\
\hline & & Normal & Head defect & Tail defect & Live & Dead \\
\hline \multicolumn{7}{|l|}{ Treatment } \\
\hline $\begin{array}{l}\mathrm{N} \\
(n=6)\end{array}$ & $1.03 \pm 0.05^{\mathrm{a}}$ & $82.61 \pm 0.03^{a}$ & $3.69 \pm 0.01^{b}$ & $13.50 \pm 0.02^{\mathrm{b}}$ & $93.88 \pm 0.01^{\mathrm{a}}$ & $6.12 \pm 0.01^{b}$ \\
\hline $\begin{array}{l}\mathrm{NC} \\
(n=6)\end{array}$ & $1.31 \pm 0.04^{\mathrm{b}}$ & $88.04 \pm 0.02^{b}$ & $1.77 \pm 0.01^{\mathrm{a}}$ & $9.93 \pm 0.02^{\mathrm{a}}$ & $95.46 \pm 0.01^{b}$ & $4.54 \pm 0.01^{\mathrm{a}}$ \\
\hline
\end{tabular}

${ }^{\mathrm{ab}}$ Superscripts within the same column show significant difference $(P<0.05)$.

TABLE 2: Sperm motility, morphology, and vitality of Habbatus sauda (HS) and Habbatus sauda Control (HSC) groups.

\begin{tabular}{|c|c|c|c|c|c|c|}
\hline \multirow{2}{*}{ Parameter } & \multirow{2}{*}{$\begin{array}{c}\text { Motility }\left(\times 10^{6} \text { sperm } / \mathrm{mL}\right) \\
(\text { mean } \pm \text { SE })\end{array}$} & \multicolumn{3}{|c|}{ Morphology (\%) (mean \pm SE) } & \multicolumn{2}{|c|}{ Vitality $(\%)($ mean \pm SE) } \\
\hline & & Normal & Head defect & Tail defect & Live & Dead \\
\hline \multicolumn{7}{|l|}{ Treatment } \\
\hline $\begin{array}{l}\text { HS } \\
(n=6)\end{array}$ & $1.49 \pm 0.04^{\mathrm{b}}$ & $90.61 \pm 0.01^{b}$ & $2.19 \pm 0.00^{\mathrm{a}}$ & $7.06 \pm 0.01^{\mathrm{a}}$ & $96.98 \pm 0.01^{b}$ & $3.02 \pm 0.01^{\mathrm{a}}$ \\
\hline $\begin{array}{l}\text { HSC } \\
(n=6)\end{array}$ & $1.33 \pm 0.06^{\mathrm{a}}$ & $85.15 \pm 0.02^{\mathrm{a}}$ & $2.71 \pm 0.00^{\mathrm{a}}$ & $11.98 \pm 0.02^{\mathrm{b}}$ & $92.93 \pm 0.01^{\mathrm{a}}$ & $7.07 \pm 0.01^{\mathrm{b}}$ \\
\hline
\end{tabular}

${ }^{\mathrm{ab}}$ Superscripts within the same column show significant difference $(P<0.05)$.

\section{Results}

\subsection{Sperm Parameters}

3.1.1. Effects of Nicotine on Sperm Parameters. Intramuscular administration of $0.5 \mathrm{mg} / 100 \mathrm{~g}$ nicotine for a period of 100 days negatively affected all sperm parameters studied (Table 1). It significantly lowered sperm motility $(1.03 \pm 0.05 \times$ $\left.10^{6} \mathrm{sperm} / \mathrm{mL}\right)$ compared to the control group $(1.31 \pm 0.04 \times$ $\left.10^{6} \mathrm{sperm} / \mathrm{mL}\right)(P<0.05)$. The $\mathrm{N}$ group had a significantly lower percentage of normal sperm $(82.61 \pm 0.03 \%)$ besides having a significantly higher percentage of abnormal head $(3.69 \pm 0.01 \%)$ and tail defect $(13.50 \pm 0.02 \%)$ sperm when compared to the NC group $(P<0.05)$. A significantly lower percentage of live sperm $(93.88 \pm 0.01 \%)$ and a significantly higher percentage of dead sperm $(6.12 \pm 0.01 \%)$ were recorded for rats in the $\mathrm{N}$ group compared to the $\mathrm{NC}$ group $(P<0.05)$.

3.1.2. Effects of HS on Sperm Parameters. Oral administration of $6.0 \mu \mathrm{L} / 100 \mathrm{~g}$ Habbatus sauda oil performed on rats for a period of 100 days had positive effects on all sperm parameters studied, except for the presence of sperm with abnormal head defects (Table 2). The treatment significantly increased sperm motility $\left(1.49 \pm 0.04 \times 10^{6} \mathrm{sperm} / \mathrm{mL}\right)$ compared to the control group $\left(1.33 \pm 0.06 \times 10^{6} \mathrm{sperm} / \mathrm{mL}\right)$ $(P<0.05)$. The percentage of normal sperm $(90.61 \pm 0.01 \%)$ was significantly higher while the percentage of sperm with tail defects $(7.06 \pm 0.01 \%)$ was lower compared to the control group $(P<0.05)$. A significantly higher percentage of live sperm was observed for the HS group $(96.98 \pm 0.01 \%)$, which also had a significantly lower percentage of dead sperm $(3.02 \pm 0.01 \%)$ compared to the HSC group $(P<0.05)$.

\subsection{Testis Histological Features}

3.2.1. Testis Histological Features of Nicotine-Treated Rats. Significantly higher values were obtained for the $\mathrm{N}$ group for all testis histological features studied, except for the width of spermatid-sperm layer (Figures $1(\mathrm{a})$ and $1(\mathrm{~b})$ and Table 3). Bigger seminiferous tubule diameter (253.36 \pm $1.83 \mu \mathrm{m})$ and lumen diameter $(100.15 \pm 2.38 \mu \mathrm{m})$ were found. Thicker spermatogonia layer $(19.85 \pm 0.39 \mu \mathrm{m})$ and spermatocytes layer $(33.37 \pm 0.59 \mu \mathrm{m})$ were observed, in contrast to spermatid-sperm layer $(22.14 \pm 0.71 \mu \mathrm{m})$ which was significantly thinner than the NC group $(P<0.05)$.

3.2.2. Testis Histological Features of Habbatus sauda-Treated Rats. Generally, Habbatus sauda treatment gave mixed results of the features studied (Figures 1(c) and 1(d) and Table 4). The HS group had a significantly smaller lumen diameter $(67.53 \pm 2.34 \mu \mathrm{m})$ and thinner spermatogonia layer $(17.67 \pm 0.32 \mu \mathrm{m})$, although a significantly thicker spermatidsperm layer $(36.95 \pm 0.79 \mu \mathrm{m})$ as compared to the HSC group was observed $(P<0.05)$. No significant difference was detected for both the diameter of seminiferous tubule and the thickness of the spermatocytes layer.

\section{Discussion}

Rats were chosen as the experimental animal in this research for their well-defined reproductive systems and the fact that compounds which could cause infertility in human males were also found to be active in rats [26]. The findings of the current research suggested that nicotine could cause harmful effects on the sperm quality and spermatogenic cell arrangement of male rats while Nigella sativa oil tended to improve it. Comparatively, this research used a lower 


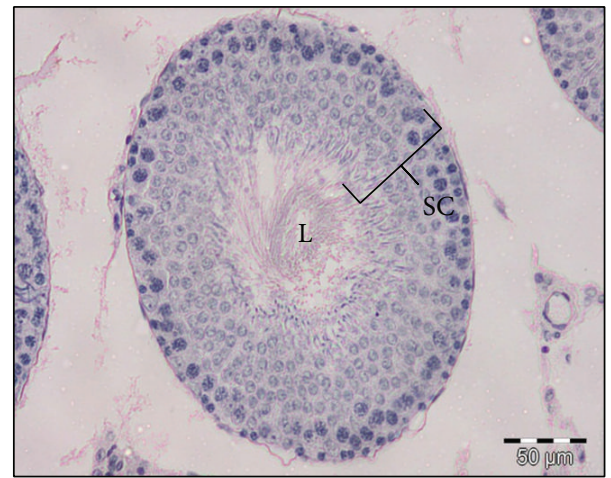

(a)

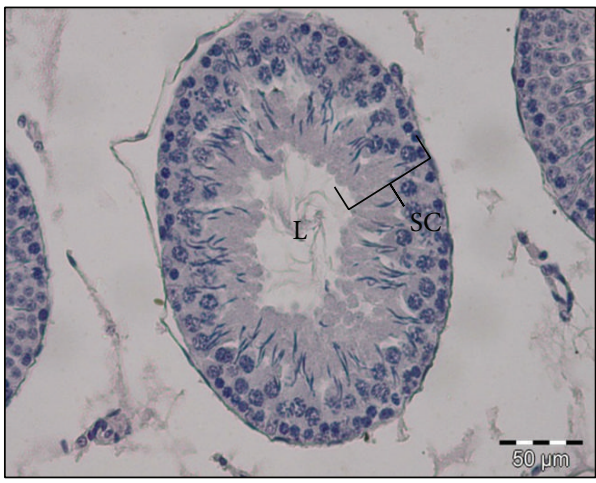

(c)

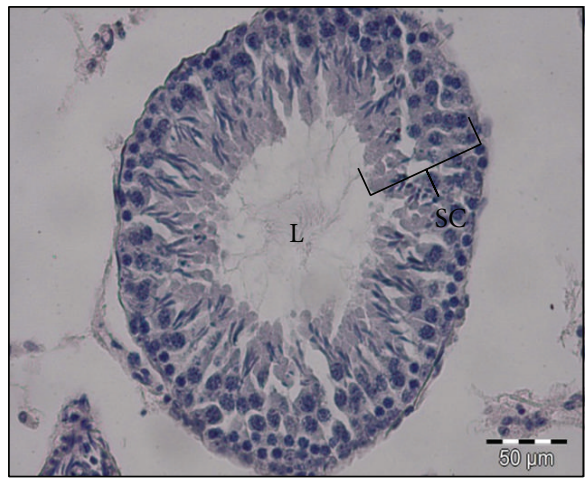

(b)

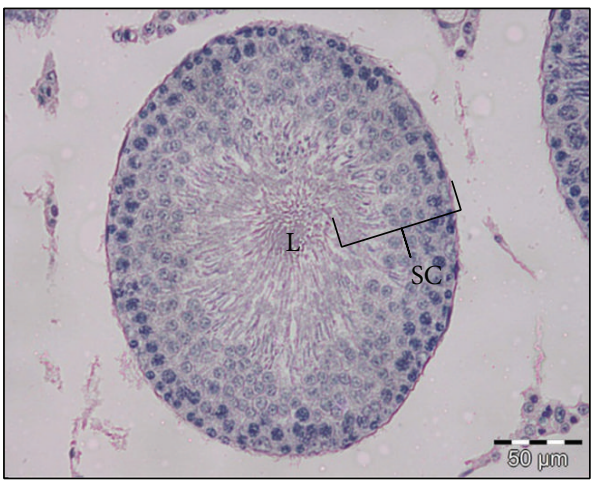

(d)

Figure 1: Seminiferous tubules at 200x magnification for (a) NC group, (b) N group, (c) HSC group, and (d) HS group. Note: L = lumen of seminiferous tubule and SC = spermatogenic cells.

TABLE 3: Testis histological features of Nicotine (N) and Nicotine Control (NC) treated rats.

\begin{tabular}{|c|c|c|c|c|c|}
\hline Parameter & $\begin{array}{c}\text { Diameter of } \\
\text { seminiferous } \\
\text { tubules } \\
(\mu \mathrm{m}) \\
(\text { mean } \pm \mathrm{SE})\end{array}$ & $\begin{array}{c}\text { Diameter of lumen } \\
(\mu \mathrm{m}) \\
(\text { mean } \pm \mathrm{SE})\end{array}$ & $\begin{array}{c}\text { Width of } \\
\text { spermatogonia } \\
\text { layer } \\
(\mu \mathrm{m}) \\
(\text { mean } \pm \mathrm{SE})\end{array}$ & $\begin{array}{c}\text { Width of } \\
\text { spermatocytes } \\
\text { layer } \\
(\mu \mathrm{m}) \\
(\text { mean } \pm \mathrm{SE})\end{array}$ & $\begin{array}{c}\text { Width of } \\
\text { spermatid-sperm } \\
\text { layer } \\
(\mu \mathrm{m}) \\
(\text { mean } \pm \mathrm{SE})\end{array}$ \\
\hline \multicolumn{6}{|l|}{ Treatment } \\
\hline $\begin{array}{l}\mathrm{N} \\
(n=6)\end{array}$ & $253.36 \pm 1.83^{b}$ & $100.15 \pm 2.38^{b}$ & $19.85 \pm 0.39^{b}$ & $33.37 \pm 0.59^{b}$ & $22.14 \pm 0.71^{\mathrm{a}}$ \\
\hline $\begin{array}{l}\mathrm{NC} \\
(n=6)\end{array}$ & $242.75 \pm 1.24^{\mathrm{a}}$ & $79.64 \pm 2.01^{\mathrm{a}}$ & $18.82 \pm 0.27^{\mathrm{a}}$ & $30.95 \pm 0.34^{\mathrm{a}}$ & $25.40 \pm 0.78^{\mathrm{b}}$ \\
\hline
\end{tabular}

${ }^{\mathrm{ab}}$ Superscripts within the same column show significant difference $(P<0.05)$.

TABle 4: Testis histological features of Habbatus sauda (HS) and Habbatus sauda Control (HSC) treated rats.

\begin{tabular}{|c|c|c|c|c|c|}
\hline Parameter & $\begin{array}{l}\text { Diameter of } \\
\text { seminiferous } \\
\text { tubules } \\
(\mu \mathrm{m}) \\
(\text { mean } \pm \mathrm{SE})\end{array}$ & $\begin{array}{l}\text { Diameter of lumen } \\
\qquad(\mu \mathrm{m}) \\
(\text { mean } \pm \mathrm{SE})\end{array}$ & $\begin{array}{c}\text { Width of } \\
\text { spermatogonia } \\
\text { layer } \\
(\mu \mathrm{m}) \\
(\text { mean } \pm \mathrm{SE})\end{array}$ & $\begin{array}{c}\text { Width of } \\
\text { spermatocytes } \\
\text { layer } \\
(\mu \mathrm{m}) \\
(\text { mean } \pm \mathrm{SE})\end{array}$ & $\begin{array}{c}\text { Width of } \\
\text { spermatid-sperm } \\
\text { layer } \\
(\mu \mathrm{m}) \\
(\text { mean } \pm \mathrm{SE})\end{array}$ \\
\hline \multicolumn{6}{|l|}{ Treatment } \\
\hline $\begin{array}{l}\text { HS } \\
(n=6)\end{array}$ & $252.15 \pm 1.76^{\mathrm{a}}$ & $67.53 \pm 2.34^{\mathrm{a}}$ & $17.67 \pm 0.32^{\mathrm{a}}$ & $34.57 \pm 0.50^{\mathrm{a}}$ & $36.95 \pm 0.79^{\mathrm{b}}$ \\
\hline $\begin{array}{l}\text { HSC } \\
(n=6)\end{array}$ & $255.97 \pm 1.81^{\mathrm{a}}$ & $92.22 \pm 2.41^{\mathrm{b}}$ & $19.04 \pm 0.36^{\mathrm{b}}$ & $33.66 \pm 0.48^{\mathrm{a}}$ & $27.12 \pm 0.80^{\mathrm{a}}$ \\
\hline
\end{tabular}

${ }^{\mathrm{ab}}$ Superscripts within the same column show significant difference $(P<0.05)$. 
dose of chronic nicotine treatment, while others had used higher acute nicotine treatment, for example, $20.0 \mathrm{mg} / \mathrm{kg}$ body weight $(2.0 \mathrm{mg} / 100 \mathrm{~g}$ body weight $)$ and $30.0 \mathrm{mg} / \mathrm{kg}$ body weight $(3.0 \mathrm{mg} / 100 \mathrm{~g}$ body weight $)$ of aqueous extract of Nicotiana tabacum on the male albino Wistar rats for 21 days [27]. The current research is similar to the one which used nicotine at a dose of $0.4 \mathrm{mg} / 100 \mathrm{~g}$ body weight daily for 3 months but limited to the effects on the ultrastructure of the rat testis [28].

The male Sprague-Dawley rats chronically treated with nicotine for a period of 100 days, as done in this research, showed a decrease in sperm motility. These findings were in line with studies, which found that sperm count and motility of human males were adversely affected by smoking behaviour [29]. Nicotine administration of $0.5 \mathrm{mg} / \mathrm{kg}$ and $1.0 \mathrm{mg} / \mathrm{kg}$ per body weight on rats daily for 4 weeks also found that sperm motility of rats was lowered compared to the control group [30]. Nicotine and cotinine also caused a negative effect on motility, spermatogenesis, epididymal sperm count, and fertilizing potential of sperm [6]. The male albino Wistar rats treated with $20.0 \mathrm{mg} / \mathrm{kg}$ body weight and $30.0 \mathrm{mg} / \mathrm{kg}$ body weight of aqueous extract of Nicotiana tabacum for 21 days also showed decreased sperm count and sperm motility [27].

Similarly, it was found that the normal morphology of sperm was adversely affected by smoking behaviour [29]. Sperm abnormalities observed in rats treated with nicotine might be due to low production of testosterone and the DNAdamaging effects caused by nicotine [31]. In addition, an increase in reactive oxygen species (ROS) level caused by nicotine would also lead to morphological defects on sperm, since mammalian sperms are rich in polyunsaturated fatty acids and are susceptible to attack by ROS [32]. Present results showed that sperm vitality of rats treated with nicotine also showed negative feedback, hence agreeing with findings of a reduction in percentage of live sperm in a study carried out in a dose-dependent manner [30].

Since pure Nigella sativa oil was used in the present research, the findings obtained could be due to thymoquinone, which has been identified as the major and active compound of Nigella sativa by pharmacological studies, and/or other active compounds present in Nigella sativa oil [17]. Currently, there is no report on which compound of Nigella sativa would contribute to fertility in males; hence, the possibility of pure Nigella sativa oil as a complementary alternative substance to improve fertility of the males [33].

Our preliminary research using Nigella sativa oil at $2.0 \mu \mathrm{L} / 100 \mathrm{~g}$ body weight for 60 days did not show any significant results on sperm parameters. The present research discovered that rats given an oral administration of Habbatus sauda oil at $6.0 \mu \mathrm{L} / 100 \mathrm{~g}$ body weight for 100 days had increased sperm motility. Oral administration of Nigella sativa would increase sperm motility from cauda epididymis [34]. This increment on sperm motility might be due to the effects of Nigella sativa on oxidative phosphorylation enzymes [35]. In addition, alloxan diabetic male rats showed improvement in semen quantity and mobility after being orally administered with Nigella sativa at the dose of $2 \%$ of its diet for 30 days [36].

Current results obtained on sperm morphology were in agreement with the work which showed that rats given oral administration of Nigella sativa oil at a dose of $0.5 \mathrm{~mL} /$ day had reduced sperm abnormalities [20]. These findings were correlated with the antioxidant properties of thymoquinone, which is the main constituent of Nigella sativa oil [37]. Rats treated with Habbatus sauda oil in this current research also had a higher percentage of live sperm compared to the control group. Rats treated with Nigella sativa for a shorter period of 53 days tended to have increased sperm viability [34].

Results of testis histological features studied gave indications to the spermatogenesis process. In this research, rats treated with nicotine demonstrated less mature sperm in the seminiferous tubule. Thus, our research shared similar findings with a study which found a slight decrease in spermatogenic series and sperm count in seminiferous tubules of male Swiss albino mice treated with nicotine for durations of both one week and two weeks [38]. Male Wistar rats treated with varied doses of nicotine for 30 days also showed a reduction in germ cells and spermatids of their seminiferous tubules [39]. On the other hand, some temporary defects on testes histopathology of rats aged 7 weeks when exposed to nicotine were also reported [40]. In addition, male Wistar rats treated with nicotine for 90 days showed notable deterioration changes in seminiferous tubules, spermatids, and the Sertoli cells [6].

As for testis parameters of rats treated with Habbatus sauda oil, findings in this research were in line with a report of increased number of spermatids in Nigella sativa-treated rats [34]. Since thymoquinone is the major constituent found in Nigella sativa, it was believed to have protective effects on testicular parameters [41]. In another study, the protective effects of thymoquinone on testicular parameters had been proven [42]. In addition, coadministration of cisplatin and Nigella sativa oil on rats for a period of 21 days showed an evident improvement in the structure of testes [43].

Generally, nicotine treatment was known to increase lipid levels and lipid peroxidation products in serum and testis of rats $[44,45]$. It was also reported that nicotine administration disrupted the components of the free radical defence system and tended to exert oxidative stress in germ cells $[46,47]$. The free radicals produced would lead to cellular injury. The structure and fluidity of cell membrane would be altered when membrane phospholipids and lipid peroxidation were disintegrated, marked by the release of unsaturated fatty acid from membrane phospholipids $[48,49]$. Based on results of our present research, decreases in sperm quality and testis histological features observed in nicotine-treated rats may be due to an increased oxidative degradation of phospholipids.

\section{Conclusion}

In conclusion, this research advocates that nicotine tended to reduce quality of sperm and affect the arrangement of spermatogenic cells while Habbatus sauda oil could enhance the quality of sperm and gave better features of testis histology. 


\section{Conflict of Interests}

All authors have no commercial or financial conflict of interests in the products described in this research paper.

\section{Acknowledgments}

This work is supported by the University of Malaya Research Grants (UMRG): RG212/11AFR and RG202/11AFR.

\section{References}

[1] W. D. Mosher and W. F. Pratt, "Fecundity and infertility in the United States: incidence and trends," Fertility and Sterility, vol. 56, no. 2, pp. 192-193, 1991.

[2] S. F. Ibrahim, K. Osman, S. Das, A. M. Othman, N. A. Majid, and M. P. A. Rahman, "A study of the antioxidant effect of alpha lipoic acids on sperm quality," Clinics, vol. 63, no. 4, pp. 545-550, 2008.

[3] D. Hammond, G. T. Fong, K. M. Cummings, R. J. O’Connor, G. A. Giovino, and A. McNeill, "Cigarette yields and human exposure: a comparison of alternative testing regimens," Cancer Epidemiology Biomarkers and Prevention, vol.15, no. 8, pp. 14951501, 2006.

[4] P. Seema, S. S. Swathy, and M. Indira, "Protective effect of selenium on nicotine-induced testicular toxicity in rats," Biological Trace Element Research, vol. 120, no. 1-3, pp. 212-218, 2007.

[5] F. R. da Silva, B. Erdtmann, T. Dalpiaz et al., "Effects of dermal exposure to Nicotiana Tabacum (Jean Nicot, 1560) leaves in mouse evaluated by multiple methods and tissues," Journal of Agricultural and Food Chemistry, vol. 58, no. 17, pp. 9868-9874, 2010.

[6] K. Aydos, M. C. Güven, B. Can, and A. Ergün, "Nicotine toxicity to the ultrastructure of the testis in rats," BJU International, vol. 88 , no. 6, pp. 622-626, 2001.

[7] N. K. Kavitharaj and P. L. Vijayammal, "Nicotine administration induced changes in the gonadal functions in male rats," Pharmacology, vol. 58, no. 1, pp. 2-7, 1999.

[8] A. McDonald, A Botanical Perspective on the Identity of Soma (Nelumbo Nucifera Gaertn.) Based on Scriptural and Iconographic Records, Botanical Garden Press, New York, NY, USA, 2004.

[9] S. C. D'Cruz, S. Vaithinathan, R. Jubendradass, and P. P. Mathur, "Effects of plants and plant products on the testis," Asian Journal of Andrology, vol. 12, no. 4, pp. 468-479, 2010.

[10] World Health Organization, Traditional Medicine Strategy: 2002-2005, WHO, Geneva, Switzerland, 2002.

[11] M. Tariq, "Nigella sativa seeds: folklore treatment in modern day medicine," Saudi Journal of Gastroenterology, vol. 14, no. 3, pp. 105-106, 2008.

[12] A. K. Nadkarni, Indian Materia Medica, Popular Prakashan, Bombay, India, 1976.

[13] B. Meddah, R. Ducroc, M. E. A. Faouzi et al., "Nigella sativa inhibits intestinal glucose absorption and improves glucose tolerance in rats," Journal of Ethnopharmacology, vol. 121, no. 3, pp. 419-424, 2009.

[14] K. Usmanghani, A. Saeed, and M. T. Alam, Indusyunic Medicine: Traditional Medicine of Herbal, Animal and Mineral Origin in Pakistan, B. C. C. and T. Press, University of Karachi, Karachi, Pakistan, 1997.
[15] B. H. Ali and G. Blunden, "Pharmacological and toxicological properties of Nigella sativa," Phytotherapy Research, vol. 17, no. 4, pp. 299-305, 2003.

[16] V. Hajhashemi, A. Ghannadi, and H. Jafarabadi, "Black cumin seed essential oil, as a potent analgesic and anti-inflammatory drug," Phytotherapy Research, vol. 18, no. 3, pp. 195-199, 2004.

[17] H. Gali-Muhtasib, N. El-Najjar, and R. Schneider-Stock, "The medicinal potential of black seed (Nigella sativa) and its components," Advances in Phytomedicine, vol. 2, pp. 133-153, 2006.

[18] S. Chandra, S. N. Murthy, D. Mondal, and K. C. Agrawal, "Therapeutic effects of Nigella sativa on chronic HAART-induced hyperinsulinemia in rats," Canadian Journal of Physiology and Pharmacology, vol. 87, no. 4, pp. 300-309, 2009.

[19] M. S. Butt and M. T. Sultan, "Nigella sativa: reduces the risk of various maladies," Critical Reviews in Food Science and Nutrition, vol. 50, no. 7, pp. 654-665, 2010.

[20] A. E. Samir Bashandy, "Effect of fixed oil of Nigella sativa on male fertility in normal and hyperlipidemic rats," International Journal of Pharmacology, vol. 3, no. 1, pp. 27-33, 2007.

[21] J. A. A. Al-Sa'aidi, A. L. D. Al-Khuzai, and N. F. H. Al-Zobaydi, "Effect of alcoholic extract of Nigella sativa on fertility in male rats," Iraqi Journal of Veterinary Sciences, vol. 23, supplement 2, pp. 123-128, 2009.

[22] A. N. Al-Dejyli, Study the effect of Alkaloid and phenolic extract of the red onion Allium csepa L. on white male and female mice [Ph.D. thesis], Collage of Science, Babil University, Babil, Iraq, 2001.

[23] R. I. Mclachlan, L. O’Donnell, S. J. Meachem, and D. M. Stanon, "Identification of specific sites of hormonal regulation in spermatogenesis," Journal of Clinical Endocrinology and Metabolism, vol. 57, pp. 149-179, 2002.

[24] NAFA (Nordic Association for Andrology) \& ESHRE (European Society of Human Reproduction and Embryology)-SIGA (Special Interest Group on Andrology), Manual on Basic Semen Analysis, 2002.

[25] World Health Organization, WHO Laboratory Manual for Examination of Human Semen and Semen-Cervical Mucus Interaction, The Press Syndicate of The University of Cambridge, Cambridge, UK, 4th edition, 1999.

[26] B. Andrzej, D. W. Hahn, R. G. Foldsey, and J. L. Megure, "Experimental studies in the development of male contraceptives," in Male Contraception, Advances and Future Prospects, G. Zatuchni, A. Goldsmith, J. M. Spieller, and J. J. Saara, Eds., pp. 158-182, Harper and Row, New York, NY, USA, 1985.

[27] M. G. Ibraheem, Z. G. Nanyak, A. Glory et al., "The effect of aqueous leave extract of Nicotiana Tabacum (Tobacco) on some reproductive parameters and micro-anatomical architecture of the testis in male albino wistar rats," Journal of Natural Sciences Research, vol. 3, supplement 5, pp. 137-143, 2013.

[28] K. Aydos, M. C. Güven, B. Can, and A. Ergün, "Nicotine toxicity to the ultrastructure of the testis in rats," BJU International, vol. 88 , no. 6, pp. 622-626, 2001.

[29] A. H. Colagar, G. A. Jorsaraee, and E. T. Marzony, "Cigarette smoking and the risk of male infertility," Pakistan Journal of Biological Sciences, vol. 10, no. 21, pp. 3870-3874, 2007.

[30] I. P. Oyeyipo, Y. Raji, B. O. Emikpe, and A. F. Bolarinwa, "Effects of nicotine on sperm characteristics and fertility profile in adult male rats: a possible role of cessation," Journal of Reproduction and Infertility, vol. 12, no. 3, pp. 201-207, 2011.

[31] K. Jana, P. K. Samanta, and D. K. De, "Nicotine diminishes testicular gametogenesis, steroidogenesis, and steroidogenic 
acute regulatory protein expression in adult albino rats: Possible influence on pituitary gonadotropins and alteration of testicular antioxidant status," Toxicological Sciences, vol. 116, no. 2, pp. 647-659, 2010.

[32] I. Ates, H. S. Suzen, A. Aydin, and A. Karakaya, “The oxidative DNA base damage in testes of rats after intraperitoneal cadmium injection," BioMetals, vol. 17, no. 4, pp. 371-377, 2004.

[33] A. Aftab, H. Asif, M. Mohd et al., "A review on therapeutic potential ofNigella sativa: a miracle herb," Asian Pacific Journal of Tropical Biomedicine, vol. 3, supplement 5, pp. 337-352, 2013.

[34] A. M. Mukhallad, M. J. M. Mohamad, and D. Hatham, "Effects of black seeds (Nigella sativa) on spermatogenesis and fertility of male albino rats," Research Journal of Medicine and Medical Sciences, vol. 4, supplement 2, pp. 386-390, 2009.

[35] C. Azzarito, L. Boiardi, W. Vergoni, M. Zini, and I. Portioli, "Testicular function in hypercholesteromic male patients during prolonged simvastatine treatment," Hormone and Metabolic Research, vol. 28, no. 4, pp. 193-198, 1996.

[36] Z. Ghlissi, K. Hamden, M. Saoudi et al., "Effect of Nigella sativa seeds on reproductive system of male diabetic rats," African Journal of Pharmacy and Pharmacology, vol. 6, supplement 20, pp. 1444-1450, 2012.

[37] G. Lupidi, A. Scire, E. Camaioni et al., "Thymoquinone, a potential therapeutic agent of Nigella sativa, binds to site I of human serum albumin," Phytomedicine, vol. 17, no. 10, pp. 714720, 2010.

[38] A. M. Gawish, S. Ramadan, A. M. Hassan, and A. M. Issa, "Morphometrical, histopathological, and cytogenetical ameliorating effects of green tea extract on nicotine toxicity of the testis of rats," Journal of Cytology and Histology, vol. 1, supplement 2, pp. $1-7,2010$.

[39] U. G. Egesie, N. Z. Galam, I. M. Gambo et al., "Evaluation of andrological indices and testicular histology following administration of varied doses of nicotine," Journal of Biology, Agriculture and Healthcare, vol. 3, supplement 2, pp. 83-94, 2013.

[40] M. Anzar, M. Buhr, P. Mirshokraei, and A. C. Holloway, Fetal and Neonatal Exposure to Nicotine Adversely Affects Testicular and Epididymal Function in Rats, Society for the Study of Reproduction, Omaha, Neb, USA, 2006.

[41] A. Al-Ali, A. A. Alkhawajah, M. A. Randhawa, and N. A. Shaikh, "Oral and intraperitoneal LD50 of thymoquinone, an active principle of Nigella sativa, in mice and rats," Journal of Ayub Medical College, Abbottabad, vol. 20, no. 2, pp. 25-27, 2008.

[42] A. Gokce, S. Oktar, A. Koc et al., "Protective effect of thymoquinone in experimental testicular torsion," European Urology, vol. 9, p. 586, 2010.

[43] E. A. Awadalla, "Ameliorative effect of the crude oil of the Nigella sativa on oxidative stress induced in rat testes by cisplatin treatment," Biomedicine and Preventive Nutrition, vol. 2, pp. 265-268, 2012.

[44] M. S. Latha, P. L. Vijayammal, and P. A. Kurup, "Effect of nicotine administration on lipid metabolism in rats," Indian Journal of Medical Research B: Biomedical Research Other Than Infectious Diseases, vol. 98, pp. 44-49, 1993.

[45] L. Ashakumary and P. L. Vijayammal, "Effect of nicotine on lipoprotein metabolism in rats," Lipids, vol. 32, no. 3, pp. 311315, 1997.

[46] L. M. Bui, C. L. Keen, and M. A. Dubick, "Comparative effects of 6-week nicotine treatment on blood pressure and components of the antioxidant system in male spontaneously hypertensive
(SHR) and normotensive Wistar Kyoto (WKY) rats," Toxicology, vol. 98, no. 1-3, pp. 57-65, 1995.

[47] D. Yildiz, N. Ercal, and D. W. Armstrong, "Nicotine enantiomers and oxidative stress," Toxicology, vol. 130, no. 2-3, pp. 155-165, 1998.

[48] T. F. Slater, "Free-radical mechanisms in tissue injury," Biochemical Journal, vol. 222, no. 1, pp. 1-8, 1984.

[49] M. Bagchi, S. Mukherjee, and M. K. Basu, "Lipid peroxidation in hepatic microsomal membranes isolated from mice in health and in experimental leishmaniasis," Indian Journal of Biochemistry and Biophysics, vol. 30, no. 5, pp. 277-281, 1993. 


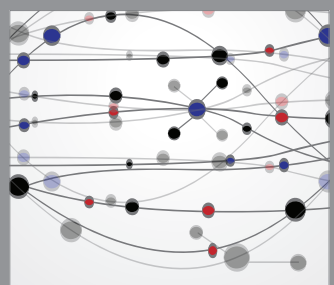

The Scientific World Journal
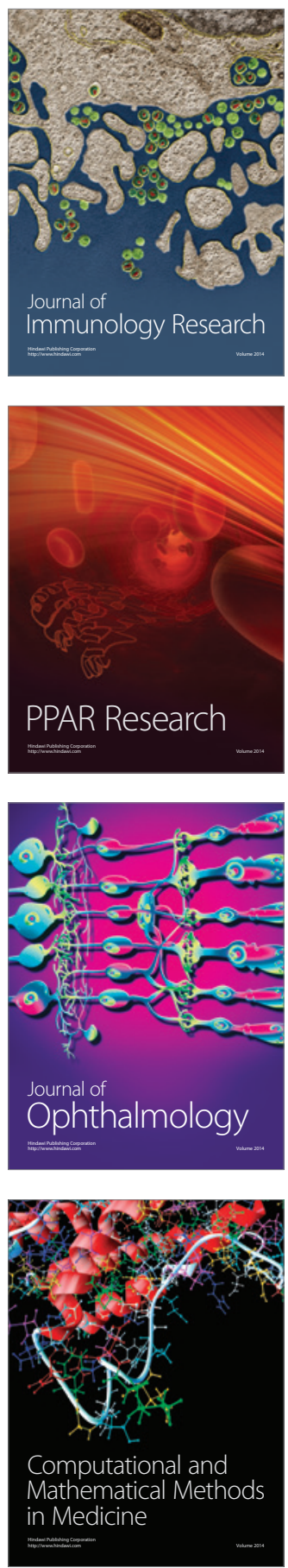

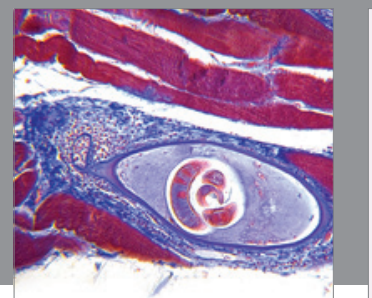

Gastroenterology

Research and Practice
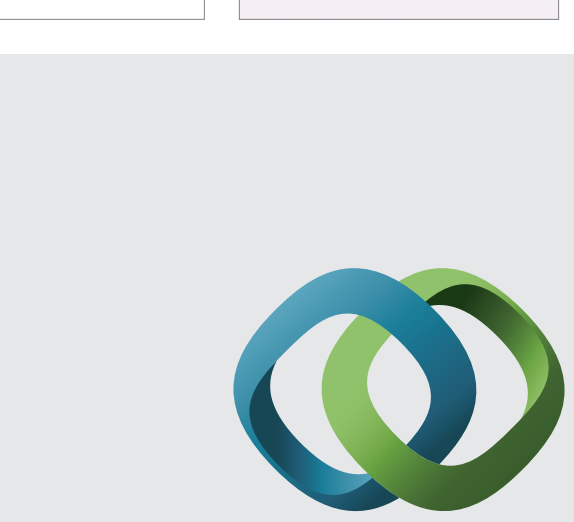

\section{Hindawi}

Submit your manuscripts at

http://www.hindawi.com
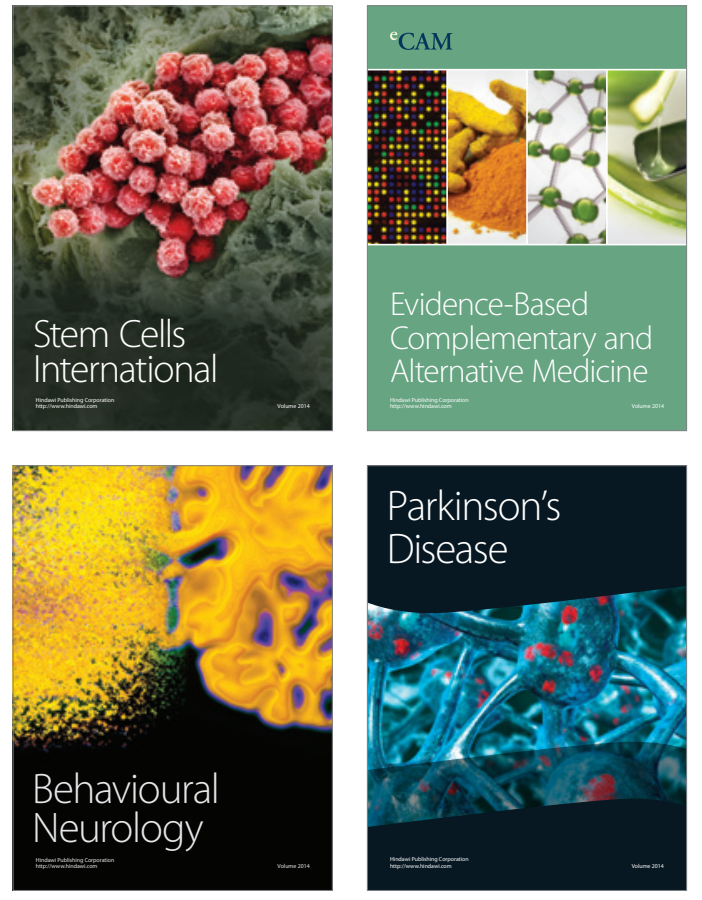
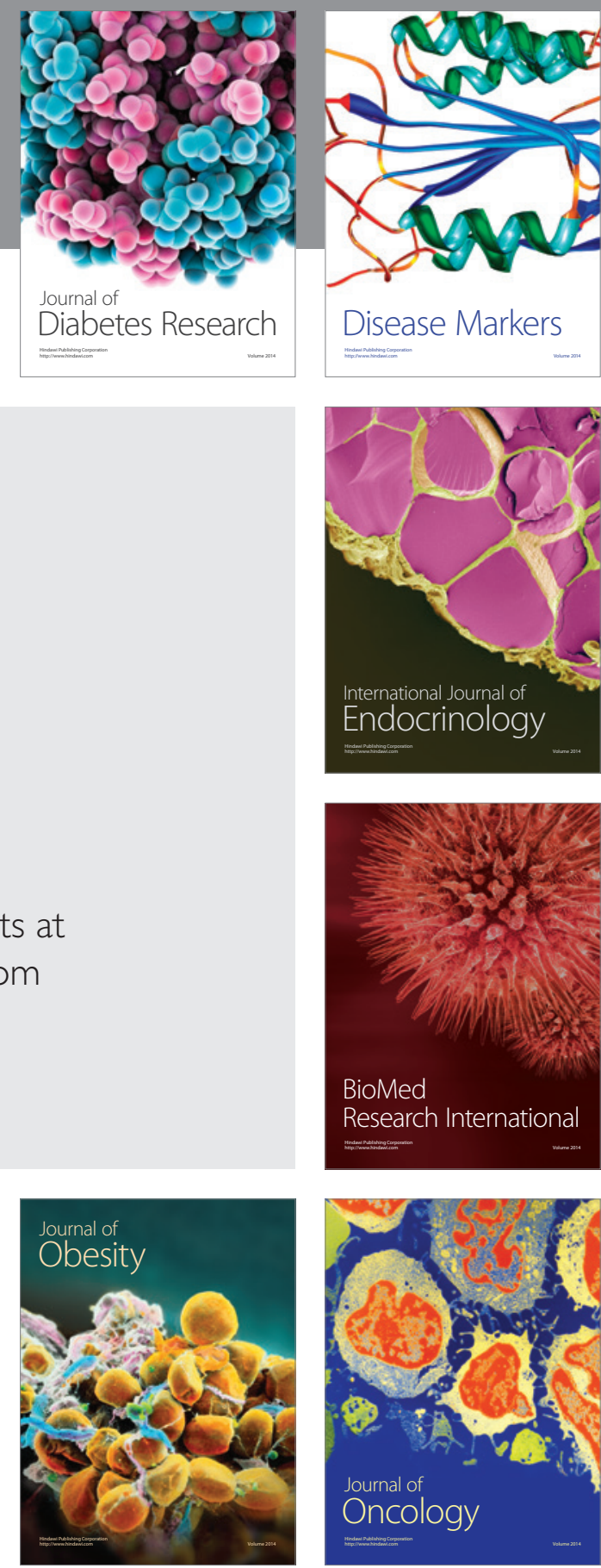

Disease Markers
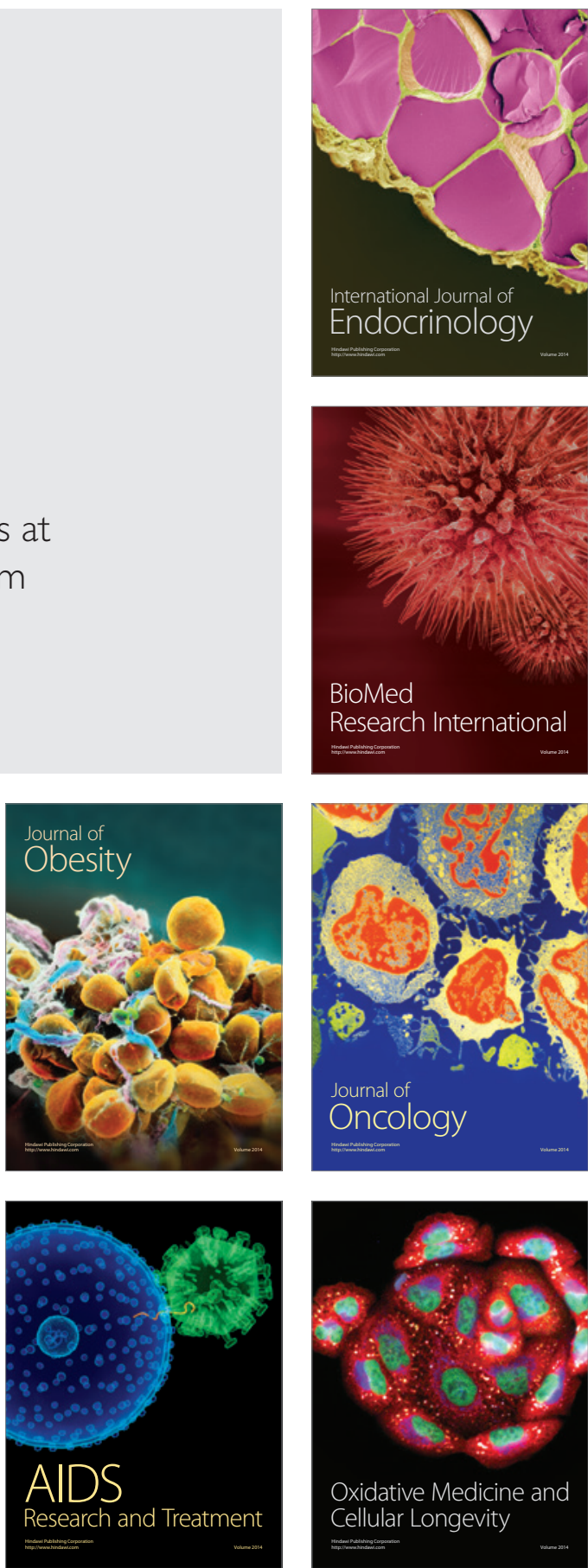